https://doi.org/10.25143/socr.13.2019.1.076-095

\title{
Prasijuma tiesību noilgums zemes likumiskajā (piespiedu) nomā
}

\author{
Arta Snipe \\ Latvijas Universitāte, Juridiskā fakultāte, \\ Doktora studiju programma \\ arta@snipe.lv
}

\section{Kopsavilkums}

Pēc Latvijas valsts neatkarības atjaunošanas uzsāktajā zemes reformā, atjaunojot bijušajiem īpašniekiem vai vinu mantiniekiem ipašuma tiesības uz zemi, uz kuras padomju varas gados bija uzceltas daudzdzīvokḷu dzīvojamās ēkas, likumdevējs radīja pamatu tā saukto dalïto īpašumu pastāvēšanai, pieņemot lēmumu zemes un ēkas īpašnieku starpā esošās attiecības regulēt atbilstoši nomas līguma noteikumiem. Šo tiesisko attiecību nodibināšanas pamats ir likums - normas, kas iekḷautas likumā "Par zemes reformu Latvijas Republikas pilsētās" un likumā "Par valsts un pašvaldību dzīvojamo māju privatizāciju".

Šā pētijjuma mērḳis ir izvērtēt dažādo tiesu praksi un dažādos juridiskajā periodikā paustos viedokḷus, interpretējot spēkā esošās tiesību normas un judikatūras atziṇas, lai identificētu prasījuma tiesību rašanās brīdi, kas ir prasījuma tiesību noilguma tecējuma sākuma brīža noteikšanas priekšnoteikums.

Pētījumā ir secināts, ka jānoškir prasījuma tiesības par zemes nomas tiesisko attiecību konstatāciju vai līguma noslēgšanu un prasijuma tiesības par nomas līguma izpildi nomas maksas samaksu. Pēdējās rodas vien pēc līguma noslēgšanas vai tiesas sprieduma spēkā stāšanās. Šajā brīdī arī sāk tecēt noilgums prasījuma tiesībām, kas izriet no noslēgtā nomas līguma. Tiesību normu interpretācijas un tiesību doktrīnas un judikatūras analīzes rezultātā pētỉjumā secināts, ka prasījuma tiesības par zemes nomas tiesisko attiecību konstatāciju vai nomas līguma noslēgšanu pret personu, kas veic daudzdzīvokḷu ēkas pārvaldīšanu un apsaimniekošanu, zemes īpašniekam rodas no brī̌̌a, kad apsaimniekotājs ir pārṇēmis konkrētās ēkas pārvaldīšanu, vai no zemes īpašuma tiesību iegūšanas brīža atkarībā no tā, kas iestājies pēdējais, savukārt prasỉjuma tiesības par zemes nomas tiesisko attiecību konstatāciju un nomas maksas piedziṇu pret atsevišķiem dzìvokḷu īpašniekiem zemes īpašniekam ir radušās vien pēc 2015. gada 1. oktobra, kopš likums piel̦auj tiešo maksājumu pieprasišanu par ēkas uzturēšanai nepieciešamajiem pakalpojumiem. 
Atslēgvārdi: zemes piespiedu noma, tiesisks darïjums, komercdarïjums, prasïjuma tiesības, noilgums, komerctiesiskais noilgums.

\section{levads}

Pēc Latvijas valsts neatkarības atjaunošanas uzsāktajā zemes reformā [8] bijušajiem īpašniekiem vai viṇu mantiniekiem tika atjaunotas īpašuma tiesỉbas uz zemes ỉpašumiem, kas no 1940. līdz 1980. gadam bija atṇemti, zemi kā nekustamo īpašumu izṇemot no civiltiesiskās aprites. Vienlaikus tika saglabātas vai piešḳirtas īpašuma tiesības uz virszemes nekustamo īpašumu - ēkām un būvēm, kas likumīgi bija uzbūvētas līdz Latvijas okupācijai vai padomju gados, - šo būvju ĩpašniekiem vai tiesiskajiem valdītājiem. Tā zemes īpašnieku un būvju īpašnieku starpā izveidojās piespiedu tiesiskās attiecības, ko likumdevējs izvēelējās regulēt atbilstoši nomas līgumu regulējošajām tiesību normām [10]. Šādas attiecības tiek dēvētas par zemes likumisko vai piespiedu nomu [49].

Tiesību zinātnē un judikatūrā ir nostiprinājusies atziṇa, ka šìs nomas attiecības pastāv neatkarīgi no pušu gribas, tām ir piespiedu raksturs [39], šìm attiecībām ir tikai nosacīta līdzỉba ar līgumiskām attiecībām [22; 64, 347], jo būtībā šìs attiecības ir likumiskas [20; 37]. Par līgumu dēvētais fakts īstenībā nav līgums [65, 109], savukārt atlīdzība nomas maksas veidā pēc juridiskās dabas pielīdzināma maksājumam par zemes īpašuma tiesību aprobežojumu [20]. Pastāvot piespiedu nomas tiesiskajām attiecībām, nav pamata runāt par lietas nodošanu lietošanā un tās pieņemšanu no otras puses, kas saskaņā ar Civillikuma vispārējās daḷas normām nodibina nomas līgumu.

Lìdz pat 2016. gadam tiesību zinātnē un tiesu praksē maz tika pētìts saistìbas un prasijuma tiesību, kas radušās uz zemes piespiedu nomas pamata, rašanās pamats un nodibināšanas brīdis, kā arī tas, vai zemes nomas maksas prasījumi ir pakḷauti vispārējam civiltiesiskajam noilgumam vai speciālajam (saīsinātajam) komerctiesiskajam noilgumam. 2017. gada sākumā, kad plašsaziṇas līdzekḷos tika aktualizēts jautājums par 10 gadu vecu zemes nomas maksas parādu piedziṇu [66; 67], savus skaidrojumus tiesību normu piemērošanā sniedza Patērētāju tiesību aizsardzības centrs [68] un Tieslietu ministrija [71]. Uz šīm publikācijām konkrētos strīdos sāka atsaukties tiesas [47; 53], kā arī atsevišḳi raksti tika publicēti juridiskajā periodikā un krājumos [57; 61].

Šã pētỉjuma pirmajā dal̦ā secināts, ka zemes piespiedu noma nav atzīstama par tiesisku darījumu Civillikuma izpratnē, un tātad tā nav atzīstama par komercdarījumu Komerclikuma izpratnē, savukārt pētījuma nākamās daḷas mērḳis ir identificēt un atrisināt prasījuma tiesību, kas saistītas ar zemes piespiedu nomu, noilguma jautājumus, šim nolūkam identificējot prasījuma tiesības, kuras ir piespiedu nomas tiesisko attiecību dalībniekiem, šo prasījuma tiesību rašanās brīdi, katra prasījuma noilguma tecējuma sākuma brīdi un noilguma pārtraukšanas iespējas. Rakstā ietverta padziḷināta tiesību normu, judikatūras, tiesu prakses un tiesību periodikā izteikto viedokḷu analīze, vērtējot pušu argumentu pamatotību, lai, pirmkārt, identificētu prasījuma tiesību pamatu, otrkārt, 
prasījuma tiesību rašanās brīdi un noilguma tecējuma sākuma brīdi, un, treškārt, secinātu, vai zemes ỉpašnieka prasījuma tiesībām, kas izriet no piespiedu nomas tiesiskajām attiecībām, ir pamats piemērot saīsinātā (komerctiesiskā) noilguma termiṇu.

\section{Prasijjuma tiesību rašanās brīdis piespiedu nomā}

Tiesību normās ir ierakstīts un Satversmes tiesas spriedumos nostiprināts, ka piespiedu noma ir atzīstama par nomas līgumu, proti, institūtu, kura vispārējais regulējums meklējams Civillikuma Saistību tiesību dạ̦ā. Pirms izvērtēt noilguma jautājumus prasījumiem, kas izriet no zemes piespiedu nomas tiesiskajām attiecībām, jāidentificē prasījuma tiesību rašanās brīdis. Lai konstatētu prasījuma tiesību rašanās brīdi, jāidentificē un jānošḳir prasijjuma tiesības, kuru rašanās pamats ir īpašuma tiesības, no prasījuma tiesībām, kas izriet no saistību tiesībām, kuru rašanās pamats ir darījums vai kuras izriet no saistības, kas radusies pēc likuma.

Civillikuma 1402. pantā [1] paredzēti vairāki saistības rašanās pamati, un piespiedu nomas tiesiskajās attiecībās saistības var pastāvēt gan uz likuma pamata, gan arī uz pušu starpā rakstveidā noslēgta nomas līguma pamata. Ja puses ir noslēgušas rakstveida nomas līgumu, tās var vienoties par līguma noteikumiem: papildu platības nomu, nomas maksas apmēru un tās samaksas termiṇiem. Ja līgums nav noslēgts, prasījuma tiesību un atbilstošo pienākumu saturs ir tāds, kāds noteikts likumā. Tāpēc katrā konkrētā situācijā būtiski ir noskaidrot faktiskos apstākḷus. Vai nomas attiecības un no tām izrietošais prasījums izriet no tiesiska darījuma (komercdarījuma, ja kāda no darījuma pusēm ir komersants) vai arī prasījums izriet no likuma? Tāpat atšḳirīgs ir prasījuma tiesību saturs un rašanās brīdis pret dažādiem subjektiem: daudzdzīvokḷu dzīvojamās ēkas gadījumā tas var būt gan pārvaldnieks vai cita pilnvarota persona, gan arī pats dzīvokḷa īpašnieks.

\section{Nomas līgums ir noslēgts rakstveidā}

Ja puses ir noslēgušas rakstveida līgumu (cita līguma forma kop̌̌ 2009. gada 1. novembra netiek piel̦auta attiecībā uz nomas maksas apmēru privatizējamās vai privatizētās un kooperatīvajās mājās saskaṇā ar likuma "Par zemes reformu Latvijas Republikas pilsētās" [10] 12. panta otro prim dạı un likuma "Par valsts un pašvaldību dzīvojamo māju privatizāciju" [9] 54. panta otro daḷu), prezumējams, ka tās tostarp ir vienojušās ne vien par nomas maksas apmēru, bet arī par tās samaksas terminiem. Prasījuma tiesības par darījuma izpildi un pielīgtās nomas maksas samaksu radīsies brīdì, kad debitors līgumu neizpildīs tajā noteiktajos termiṇos.

Zemes īpašnieks prasījuma tiesības var realizēt vien iestājoties pielīgtajam nomas maksas samaksas termiņam - pirms tam prasījums ir atzīstams par priekšlaicīgu [12; 13; 22; 31]. Prasības celšana iespējama vienīgi tad, kad notikusi indivīda tiesību 
pārkāpšana [12]. Pirms tam arī neiesākas prasījuma tiesību par līguma izpildi noilguma tecējums [1, 1896. pants]. Gadījumos, ja kāda no darījuma pusēm (ne tikai kreditors) ir komersants un rakstveidā noslēgtais darījums ir atzīstams par komercdarījumu (tas atbilst komercdarïjuma pazīmēm), prasỉjumiem, kas izriet no rakstveidā noslēgtā zemes nomas līguma, ir pamats piemērot Komerclikuma normas, kurās noteikti terminini un nosacījumi, kuros ir îstenojamas no komercdarījuma izrietošās prasījuma tiesības [61].

\section{Rakstveida nomas līgums nav noslēgts}

Ja pušu starpā rakstveida līgums nav noslēgts, tiesiskās attiecības, kā arī zemes ipašnieka prasijuma tiesības izriet no likuma: "Par zemes reformu Latvijas Republikas pilsētās" 12. panta, "Par valsts un pašvaldību dzīvojamo māju privatizāciju" 54. panta, kā arī 50. panta pirmās dal̦as un Dzìvojamo māju pārvaldīšanas likuma [2] 6. panta otrās daḷas 4. punkta un 17. ${ }^{7}$ panta. Būtiski ir nošḳirt zemes īpašnieka prasījuma tiesības par zemes nomas tiesisko attiecību konstatāciju vai nomas līguma noslēgšanu [18] no prasījuma tiesību, kas izriet no jau tiesas ceḷā vai privātautonomijas izpausmes veidā noslēgta nomas līguma, izpildes.

Likuma "Par zemes reformu Latvijas Republikas pilsētās" 12. panta trešajā daḷā, kas piemērojama pušu tiesiskajām attiecībām līdz daudzdzīvokḷu dzīvojamās ēkas nodošanai privatizācijai, noteikts, ka zemes īpašniekam ir tiesības saṇemt nomas maksu no ēku un būvju īpašnieka. Panta otrajā prim dal̦ā tiek regulēts nomas maksas apmērs. Tiesību normā nav ietverta norāde par nomas priekšmetu - tas ir jākonstatē tiesai, ja nav nodibināts ar likumu atbilstoši likuma 13. panta trešajā daḷā noteiktajam. Pusēm uz likuma pamata pastāvošajās piespiedu nomas attiecībās ir savstarpējas prasījuma tiesības uz nomas līguma noslēgšanu. Šo prasījumu mērḳis zemes ỉpašniekam, no vienas puses, ir aizsargāt viṇa likumā garantētās tiesības saṇemt no ēkas īpašnieka samaksu par zemes lietošanu, bet, no otras puses, ēkas īpašniekam - nodrošināt viṇa tiesības netraucēti valdìt un lietot viṇam piederošo ēku [21].

Likuma "Par zemes reformu Latvijas Republikas pilsētās" 12. pants ir tulkojams kā "zemes un ēkas ìpašniekam dots uzdevums savstarpēji saistīties, noslēdzot lïgumu atbilstoši brīvprātības principam, savukārt, ja vienošanās par līguma noteikumiem nenotiek - strīda gadījumā, nomas tiesisko attiecību konstatāciju (atzī̌̌anu) veic tiesa, nodibinot ar tiesas spriedumu nomas līguma būtiskās sastāvdaḷas," [28] kā tas paredzēts Civillikuma 2124. pantā. Lai gan zemes ippašniekam ir tiesības saṇemt zemes nomas maksu, tomēr šā prasījuma priekšnoteikums ir nomas tiesisko attiecību konstatācija (nodibināšana). Tikai pēc sprieduma spēkā stāšanās darījums ir atzīstams par noslēgtu, jo tikai tad ir nodibinātas darījuma būtiskās sastāvdaḷas (Civillikuma 1533. pants) [24], tiesas spriedumam aizstājot cita akta taisǐšanu [17; 28; 37]. Secīgi par darïjuma noslēgšanas brīdi atzīstams tiesas sprieduma spēkā stāšanās brīdis. Lìdzīgu skaidrojumu saistībā ar Pievienotās vērtības nodokḷa likuma 127. panta pirmās daḷas un 131. panta pirmās daḷas piemērošanu ir sniedzis Valsts ien̦ēmumu dienests, norādot, ka par zemes nomas 
pakalpojuma sniegšanas brīdi strīdus gadījumā uzskata brīdi, kad stājies spēkā spriedums par zemes nomas tiesisko attiecību konstatāciju un parāda piedziṇu, no šīs dienas skaitot piecpadsmit dienu termiṇu nodokḷa rēḳina izrakstišanai [70].

\section{Prasījuma tiesības pret ēkas pārvaldnieku}

Procesuālās ekonomijas nodrošināšanai speciālajās tiesību normās paredzētas zemes īpašnieka prasījuma tiesības pret daudzdzīvokḷu èkas pārvaldnieku prasījumā par zemes nomas līguma noslēgšanu. Tomēr šīs prasījuma tiesības ierobežo pārvaldnieka pilnvarojuma apjoms - tikai likumā noteiktā kārtībā pilnvarots pārvaldnieks var būt atbildētājs prasībā par zemes nomas līguma noslēgšanu un tā izpildi.

Ar daudzdzīvokḷu dzīvojamās ēkas privatizācijas uzsākšanu tiesiskās attiecības ēkas un zemes īpašnieku starpā sāk regulēt likuma "Par valsts un pašvaldỉbu dzīvojamo māju privatizāciju" 54. pants, kā arī 50. panta pirmās daḷas 3. punkts [62]. Šā likuma normas reglamentē dzīvokḷu īpašnieku, pārvaldnieka un zemes īpašnieka savstarpējās attiecības līdz brīdim, kad dzīvojamās mājas īpašnieki pārṇem dzīvojamās mājas pārvaldīšanas tiesības no publiskās personas, kura ēku ir privatizējusi [29].

Likuma "Par valsts un pašvaldību dzīvojamo māju privatizāciju" 54. pantā, kā arī 50. panta pirmās dal̦as 3. punktā noteikts privatizētā objekta īpašnieka "pienākums slēgt zemes nomas līgumu" vai pilnvarot dzìvojamās mājas pārvaldìtāju slēgt zemes nomas līgumu ar tā zemesgabala īpašnieku, uz kura atrodas privatizētais objekts. No otras puses, zemes ìpašnieka pienākums noslēgt nomas līgumu ar privatizētā objekta ìpašnieku noteikts likuma 54. panta pirmajā daḷā. Zemes īpašnieka prasijuma tiesības nostiprinātas likuma 54. panta ceturtajā daḷā, kurā precizēts - ja atbilstoši šã likuma 50. panta pirmās daḷas 3. punkta prasībām zemes nomas līgumi ar zemesgabala ỉpašnieku nav noslēgti, zemesgabala īpašniekam ir tiesības prasību tiesā par zemes nomas līguma noslēgšanu vērst pret personu, kurai nodotas attiecīgās dzīvojamās mājas pārvaldīšanas un apsaimniekošanas tiesības.

Šì norma expressis verbis neparedz pret pārvaldnieku vērst prasījumu par zemes nomas maksas samaksu. Tomēr "Civilprocesa likums neparedz personai iespēju tiesas ceḷā prasīt konstatēt zināmas tiesiskās attiecības esamību vai neesamību, prasībai jābūt vērstai uz konkrēta tiesību aizskāruma novēršanu" [12; 13; 23; 29; 31], bet prasījums, kas neietver mantisku prasījumu - konkrēta tiesību aizskāruma novēršanu - ir atzīstams par bezpriekšmetisku. No minētā var secināt, ka zemes īpašnieks nevar celt prasību, lai konstatētu tiesiskās attiecības esamību, neiekḷaujot mantisku prasijjumu par nomas maksas piedzinu, viņš nevar arī celt prasību par nomas tiesisko attiecību nodibināšanu nākotnē [44]. Prasījums par nomas tiesisko attiecību konstatēšanu, kas var būt vērsts tikai uz pagātni, tiek atzīts par pakārtotu prasījumu, kas nepieciešams nomas parāda noteikšanai [43]. Tiesa nomas tiesiskās attiecības var konstatēt, nosakot to būtiskās sastāvdaḷas, vien pagātnē un nosacītā tagadnē - līdz brīdim, kad tiek pabeigta lietas izskatīšana pēc būtïbas. Prasība par piespiedu nomas tiesisko attiecibu nodibināšanu uz termiṇu, kurš vēl 
nav iestājies, nav iespējama, jo šāds prasījums ietvertu tikai hipotētiskus apgalvojumus, kas nav pierādāmi, piemēram, nākotnes atbildētājs, prasījuma priekšmets (funkcionāli nepieciešamais zemesgabals var tikt grozìts administratīvajā procesā noteiktajā kārtībā), nomas maksas apmērs (nomas maksas apmērs nosakāms atbilstoši normatīvajam regulējamam, kas spēkā attiecīgajā laika periodā).

Ja zemes ipašnieks labprātīgi vai tiesas ceḷā ir vienojies ar atbilstoši pilnvarotu dzīvojamās mājas pārvaldnieku vai dzīvokḷu īpašnieku pilnvarnieku par nomas līguma būtiskajām sastāvdaḷām, tiesības un pienākumi, kas izriet no šì līguma, vienlīdz attiecas un ir saistoši dzīvojamās mājas dzīvokḷu īpašniekiem, jo tieši viṇi ir zemes nomas tiesisko attiecību subjekti $[19 ; 69]$.

Likuma "Par valsts un pašvaldību dzīvojamo māju privatizāciju" 54. panta ceturtajā daḷā paredzētas prasītāja tiesības ēkas privatizācijas procesa gaitā celt vienu prasību pret ēkas pārvaldnieku, kuram attiecīgi ir regresa prasības tiesības pret ēkas dzivoklı ìpašniekiem [16]. Pret èkas pārvaldnieku zemes īpašniekam ir prasijuma tiesības par zemes nomas tiesisko attiecību konstatāciju un nomas līguma izteikšanu akta formā - būtisko sastāvdal̦u nostiprināšanu spriedumā (kā tas expressis verbis redzams no likuma 54. panta ceturtās daḷas), šo prasījumu saistot ar mantisko (parāda piedziṇas) prasījumu no brīža, kad pārvaldnieks ir pārnẹemis konkrētās ēkas pārvaldī̌anu un apsaimniekošanu, vai no zemes īpašuma tiesību iegūšanas brīža, atkarībā no tā, kas iestājies pēdējais [29]. Valsts vai pašvaldības nozīmētais un pilnvarotais pārvaldnieks ir atbildīgs par zemes nomas līguma noslēgšanu ēkās, kuras nav pārṇēmuši dzīvokḷu ỉpašnieki [26], un šis saistības, ja tās nav izpildìtas, mainoties ēkas pārvaldniekiem, kḷust saistošas nākamajam pārvaldniekam [34]. Pārvaldnieka atbildība nav aprobežota ar saistībām, ko dzīvokḷu īpašnieku kopība (kopsapulce) ir uzṇēmusies pēc jaunā pārvaldnieka izvēles. Mainoties ēkas pārvaldniekam, jaunajam pārvaldniekam ir pienākums iestāties lietā kā iepriekšejā pārvaldnieka tiesību un saistību pārṇēmējam. Par mājas apsaimniekošanu un zemes nomas līguma noslēgšanu, tostarp arī parādu nomaksu, kas izriet no mājas apsaimniekošanas vajadzībām noslēgtajiem līgumiem, atbildīgs ir dzīvojamās ēkas ikreizējais pārvaldnieks, kuram ir prasības tiesības pret dzīvokḷu ìpašniekiem [25].

Ēkā, kurā privatizācija pabeigta, ja pārvaldnieks ir noslēdzis pilnvarojuma līgumu, uzṇemoties veikt obligātās pārvaldīšanas darbības, tam ir pienākums paredzēt arī izdevumus par dzīvojamai mājai piesaistītā zemesgabala nomu, un tas nozīmē gan pienākumu informēt dzīvokḷu īpašnieku kopību, gan veikt nepieciešamo līdzekḷu iekasēšanu no mājas īpašnieka [27]. Dzīvojamo māju pārvaldīšanas likuma $17{ }^{2}$ pantā noteiktajā kārtībā noslēgta pilnvarojuma līguma esamības gadījumā zemes īpašniekam ir prasījuma tiesības pret ēkas pārvaldnieku. Šādās prasībās atbildētājs (pārvaldnieks) it kā darbojas kā ēkas dzīvokḷu īpašnieku pārstāvis, lai gan ir patstāvīgs lietas dalībnieks. Šĩ juridiskā konstrukcija nav bieži sastopama, bet tās mērḳis ir procesuālā ekonomija: ja vienā strīdus pusē ir liels daudzums iespējamo prāvnieku, tiek noteiktas šādas pārstāvības tiesības, piemēram, tās ir arī kolektīvā pārvaldījuma organizācijai Autortiesību likumā. 
Dzīvojamo māju pārvaldīšanas likuma normās, to skaitā likuma 6. panta otrās daļas 4. punktā, noteikts, ka zemes nomas līguma slēgšana ir obligāta pārvaldīšanas darbība. Judikatūrā šì norma tulkota tā, ka bez nomas līguma noslēgšanas ēkas pārvaldīšana nav iespējama $[16 ; 33]$, un tas nozīmē, ka "dzīvojamās mājas apsaimniekošanas un pārvaldīšanas līguma esamība izslēdz vajadzību pēc kāda speciāla pilnvarojuma no dzīvokḷu īpašnieku puses par zemes nomas līguma slēgšanu”. Dzìvokḷ i ipašnieku vienpusējs paziņojums par pilnvarojuma neesamību pārvaldniekam nomas līguma slēgšanai nevar ierobežot likumā noteikto pārvaldnieka pilnvaru apjomu, tostarp būt par atbildētāju prasībā $[18 ; 32 ; 35 ; 36]$. Šis princips - liegums sašaurināt likumā noteikto pilnvarojuma apjomu - nostiprināts, piemēram, attiecībā uz prokūru Komerclikuma [6] 36. panta pirmajā daḷā.

Tomēr būtiski ir nošķirt, ka pret pārvaldnieku prasība nav vēršama gadỉjumā, ja tas pārvaldīšanas tiesības nodevis un konkrēto dzīvojamo ēku vairs neapsaimnieko. Izbeidzoties pārvaldīšanas tiesībām, tikai mājas (dzīvokḷu) īpašnieki vai nākamais pārvaldnieks, ja to paredz pārvaldīšanas līgums, var risināt jautājumus, kas saistīti ar piespiedu nomas tiesiskajām attiecībām [41, 7.2. punkts].

\section{Prasijuma tiesības pret atsevišḳiem dzivokḷu îpašniekiem}

Jānošḳir ir brīdis, kad zemes īpašniekam rodas prasījuma tiesības pret ēkas pārvaldnieku, un brīdis, kad rodas prasījuma tiesības pret atsevišķu dzīvokḷu ìpašniekiem.

Vēsturiski ir nodalāmi trīs posmi ar dažādu tiesisko regulējumu:

- lïdz 2014. gada 1. oktobrim, kad Civillikuma 1068. pants liedza îstenot prasijuma tiesības pret atsevišķu dzīvokḷu īpašniekiem (ēkas kopīpašniekiem);

- no 2014. gada 1. oktobra lïdz 2015. gada 1. oktobrim, kad saistibas saturs bija noteikts ar likumu, bet tiesību normas neparedzēja atsevišķu prasījumu vēršanu pret dzīvokḷa īpašniekiem;

- no 2015. gada 1. oktobra, kad likums sāka regulēt tiešos norēḳinus pakalpojuma sniedzēja un dzīvokḷa ìpašnieka starpā.

2014. gada 1. oktobrī spēkā stājās grozìjumi likuma "Par valsts un pašvaldību dzīvojamo māju privatizāciju" 54. panta pirmajā daḷā, kas kopsakarā ar Satversmes tiesas spriedumā lietā Nr. 2011-01-01 [52] lemto radijja juridisku pamatu prasību celšanai pret atsevišḳiem dzīvokḷu ipašniekiem par zemes nomas maksas piedzinnu. Lìdz 2014. gada 1. oktobrim - atbilstoši Satversmes tiesas lemtajam un judikatūrai - prasijums par zemes nomas līguma noslēgšanu bija jāizvirza visiem zemes kopipašniekiem, ja tie ir, pret visiem dzīvokḷu īpašniekiem kā ēkas kopīpašniekiem, jo atbilstoši Civillikuma 1068. pantam tiesai nebija tiesību noteikt nomājamo platību zemes îpašnieka individuālā strīdā ar vienu dzīvokḷu īpašnieku. Tiesas pieturējās pie ieskata, ka domājamā daḷa ir bezḳermeniska lieta, ko nevar iznomāt [59; 64], to tulkojot tādējādi, ka Civillikuma 1068. pantā liegts celt prasību par zemes nomas līguma noslēgšanu kopipašniekam vai pret kopīpašnieku [38]. 
Ar pieminētajiem grozījumiem [5] likumdevējs expressis verbis likumā noteica abas nomas līguma būtiskās sastāvdaḷas: ja cena likumā bija noteikta jau kopš 2009. gada 1. novembra, tad ar 2014. gada 1. oktobri likumā imperatīvi tika noteikta arī nomājamā platība. Formāli, sākot ar 2014. gada 1. oktobri, zemes īpašniekam vairs nebija nepieciešama zemes nomas tiesisko attiecību konstatācijas prasība - līguma būtiskās sastāvdaḷas attiecībā uz privatizācijai nodotām dzīvojamām ēkām bija noteiktas likumā [54].

Vienlaikus, lai arī likumā bija nostiprinātas darījuma būtiskās sastāvdaļas, Dzīvojamo māju pārvaldǐšanas likumā līdz pat 2015. gada 30. septembrim nebija paredzēts, ka dzīvokḷu ìpašnieki varētu slēgt līgumus vai norēḳināties ar zemes īpašnieku patstāvīgi. Tikai 2014. gada 15. janvārī spēkā stājās grozījumi [4], kas Dzīvojamo māju pārvaldīšanas likumā ieviesa tā sauktos "tiešos norēḳinus" - dzīvokḷu ỉpašnieku tiesības izvēlēties, vai maksājumus par saṇemtajiem pakalpojumiem, to skaitā zemes nomu, veikt ar pārvaldnieka starpniecību vai kā tiešos maksājumus. Likuma pārejas noteikumos (15.-22. punktā) bija noteikts, ka tiešie maksājumi par pakalpojumiem uzsākami ne agrāk kā 2015. gada 30. septembrī. Lìdz šim datumam zemes īpašniekam, kā jebkuram pakalpojumu sniedzējam, likums nedeva tiesības izrakstìt rēkinus tieši dzīvokḷu īpašniekiem un formāli pat ne tiesības noskaidrot dzīvokḷu īpašnieku personas datus, lai informētu vinuus par nesamaksāto zemes nomas maksu. No likuma pārejas noteikumu 23. punkta izriet, ka līdz šim datumam zemes ìpašniekam nebija prasījuma tiesību pret katru atsevišķu dzīvokḷa īpašnieku, jo likumdevējs bija paredzējis zemes nomas - tāpat kā citu ar ēkas uzturēšanu saistīto pakalpojumu - līgumu slēgšanu nodrošināt ar mājas pārvaldnieka starpniecību, un zemes ìpašniekam līdz minētajam datumam prasījuma tiesības bija vien pret ēkas pārvaldnieku. Dzīvojamo māju pārvaldīšanas likuma pārejas noteikumu 23. punkts kopsakarā ar Civillikuma 1071. pantā nostiprināto kopīpašnieku pienākumu segt uz kopējo lietu gulošās nastas, apgrūtinājumus un lietas uzturēšanai vajadzīgos izdevumus samērīgi ar viṇu dạ̦ām un Dzīvokḷa īpašuma likuma [3] 13. panta pirmajā daḷā nostiprinātais dzīvokḷa īpašnieka pienākums segt izdevumus obligāti veicamo dzīvojamās mājas pārvaldīšanas darbību veikšanai, pie kurām pieskaitāma arī ēkas uzturēšanai nepieciešamā zemesgabala noma, - tas viss ir radījis tiesisku pamatu zemes ipašnieka prasījuma tiesību nodibināšanai pret atsevišḳiem èku dzīvokḷu īpašniekiem prasībā par zemes nomas tiesisko attiecību konstatāciju un nomas maksas piedziṇu vai prasījuma tiesības pret zemes nomas maksas piedziņu.

Attiecībā uz prasījumiem pret atsevišķu dzìvokḷ ìpašniekiem, kas radušies pēc 2015. gada 1. oktobra, var pastāvēt atšḳirīgi viedokḷi par piespiedu nomas kā darījuma noslēgšanas brīdi - darījuma būtiskās sastāvdal̦as ir noteiktas likumā, tādēl darījumu varētu atzìt par noslēgtu ar pašu zemesgabala lietošanas faktu. Tomēr šāda pieeja ir iespējama, pirmkārt, vien attiecībā uz ēkām, kurām uzsākta un nav pabeigta privatizācija, un par laikposmu, par kuru likumā nomas maksa ir viennozīmīgi noteikta, t. i., ka nevienošanās gadījumā tie ir $6 \%$ no zemesgabala kadastrālās vērtības gadā. Tomēr arī attiecībā uz šiem objektiem nevar izslēgt strīda esamību par funkcionāli nepieciešamā zemesgabala platîbu (piemēram, vai tā pareizi aprēķināta; īpaši, ja ēka atrodas uz 
vairākiem zemesgabaliem; vai pareizi aprēḳināta kadastrālā vērtība par zemes vienību, ja tā ir reǵistrēta) vai, kopš 2019. gada 1. maija, - par nomas maksas apmēru. Arī Augstākās tiesas Civillietu departaments ir apstiprinājis judikatūras tēzi, ka piespiedu nomas strīdos tiesai jāizškirir strīds par līguma būtiskām sastāvdaḷām (Civillikuma 1533. pants), nevis par nomas tiesisko attiecību atzīšanu. Ja puses nevar panākt vienošanos par blakus noteikumiem, kas nav atzīstami par būtiskām darījuma sastāvdaḷām, tad bez vienošanās par blakus noteikumiem līgums nav atzīstams par noslēgtu, kā tas noteikts Civillikuma 1534. pantā [36]. No minētā izriet, ka atbilstoši Civillikuma 1533. pantam par galīgi nodibinātu nomas līguma saturu un būtiskās sastāvdaḷas, tai skaitā parāda, apmēru un samaksas termiṇu var runāt vien pēc sprieduma spēkā stāšanās [61].

\section{Prasijuma tiesību noilgums}

Kā analizējot saistības izcelšanās pamatu un prasījuma tiesību rašanās brīdi, tāpat arī analizējot prasījuma tiesību noilguma jautājumus, ir jānošḳir prasījumi par nomas attiecību konstatēšanu un nomas līguma noslēgšanu no prasījumiem par nomas maksas samaksu. Prasījuma tiesību noilguma termiņš sāk tecēt tikai tad, kad prasījums ir nodibināts, proti, prasījuma tiesības ir radušās. Prasījuma tiesību noilguma termiṇa tecējumu pārtrauc atgādinājums gan dzīvokḷa īpašniekam, gan pilnvarotajam ēkas pārvaldniekam.

Vispārējais saistību tiesības un prasības tiesības noilguma regulējums ir ietverts Civillikumā. Saskaṇā ar Civillikuma 1893. pantu saistību tiesības izbeidzas, ja tiesīgā persona tās pienācīgi neizlieto likumā noteiktajā noilguma termiṇā. Vispārējais noilguma termin,š ir noteikts Civillikuma 1895. pantā, un paredzēts, ka visas saistību tiesības, kuras nav noteikti izn,emtas no noilguma ietekmes un kuru izlietošanai nav likumā noteikti īsāki termiṇi, izbeidzas, ja tiesīgā persona tās neizlieto desmit gadu laikā. İsāki noilguma termini ir noteikti attiecībā uz komersantu veiktajiem komercdarijumiem. Komerclikuma 406. pantā [6] paredzēts triju gadu noilgums prasijumiem, kas izriet no komercdarïjuma tiesības prasit līguma izpildi.

Civillikuma 1910. pantā noteikts, ka ar noilguma termiṇa notecējumu izbeidzas ne vien prasības tiesība, bet arī pati saistību tiesība, secīgi likumdevējs šìs abas tiesības ir nodalïjis un pakārtojis vienu otrai. Par to liecina arī Civillikuma 1896. panta formulējums: "Noilgums sāk tecēt ar to dienu, kurā prasījums ir tā nodibināts, ka pret parādnieku, kas nav izpildījis savu pienākumu, nekavējoties var celt prasību, kaut arī tomēr vēl nebūtu ne parādnieks liedzies izpildīt, ne arī kreditors viṇam to atgādinājis."

Civillikuma 1402. pantā noteikts, ka saistību tiesības rodas no tiesiska darījuma vai no neatḷautas darbỉbas, vai pēc likuma. Civillikuma 1895. pantā paredzētais 10 gadu noilguma termiņš attiecas uz ikvienu prasījumu neatkarīgi no tā rašanās pamata. Savukārt Komerclikuma D dạ̦ā, tajā skaitā Komerclikuma 406. pantā, ietvertais regulējums par prasības noilgumu attiecas tikai uz saistībām, kas izriet no tiesiska darījuma (komercdarījuma). 
Piespiedu zemes nomas tiesiskās attiecības tiek nodibinātas bez pušu gribas - saistîbu tiesība zemes un ēkas īpašnieka starpā ir nodibinājusies ar brīdi, kad abas puses ir ieguvušas īpašuma tiesības uz attiecīgi zemes un ēkas īpašumu, šajā brīdī rodoties zemes īpašnieka tiesībām celt prasību par nomas līguma noslēgšanu, nomas maksas noteikšanu, kā arī par nomas maksas piedziṇu.

Nomas tiesiskās attiecības var nodibināt arī noslēdzot rakstveida līgumu un vienojoties par nomas būtiskajām sastāvdaḷām (Civillikuma 2124. pants), kā arī nomas maksas samaksas termiṇiem. Šajā gadỉjumā prasījuma tiesības par līguma izpildi un maksājumu piedziṇu zemes īpašniekam rodas brīdī, kad nomnieks kavē pielīgtos samaksas terminusus, un šajā brīdī sāk tecēt arī noilgums šim prasījumam. Nepastāvot rakstveida līgumam, lìdz 2009. gada 1. novembrim nebija pamata runāt par nodibinātu, no nomas līguma izrietošu prasījumu par naudas samaksu, jo tiesību normās nebija noteikts precīzs zemes nomas maksas apmērs. Tāpēc atbilstoši Civillikuma 1533., 2124. un 2125. pantam nebija pamata konstatēt, ka pušu starpā būtu panākta kāda vienošanās par darỉjuma būtisku sastāvdaḷu, proti, nomas maksu. Savukārt attiecībā uz otru līguma būtisko sastāvdaḷu (nomas priekšmetu) likumā "Par valsts un pašvaldību dzīvojamo māju privatizāciju" tā imperatīvi tika noteikta tikai ar grozījumiem, kas stājās spēkā 2014. gada 1. oktobrī. Šì skaidrojošā norma attiecināma arī uz Dzīvojamo māju pārvaldīšanas likumā minēto "piesaistāmo zemesgabalu", tādējādi par nodibinātām zemes piespiedu nomas līguma būtiskajām sastāvdaḷām var runāt vien ar 2014. gada 1. oktobri [54].

Ja pušu starpā nepastāv vienošanās par nomas līguma būtiskajām sastāvdaḷām, tas vien, ka no absolūto (īpašuma) tiesību nostiprināšanas un piespiedu nomas attiecību rašanās brīža ir pagājuši vairāk nekā 10 gadi, neizbeidz piespiedu nomas tiesiskās attiecības pušu starpā vai no tām izrietošās tiesības un pienākumus. Zemes īpašniekam gan nav vairs prasijuma tiesību par zemes nomas maksas noteikšanu un nomas maksas piedziṇu par laiku, kas pārsniedz noilguma terminu - šobrīd Civillikumā norādìtos 10 gadus. Tomēr tas vien, ka zemes īpašnieks nav vērsies tiesā vai pie ēkas īpašnieka ar prasību par nomas attiecību konstatāciju vai līguma noslēgšanu, neliedz viņam to prasīt tagad un par iepriekšējiem 10 gadiem. Savukārt, ja pušu starpā ir noslēgts komercdarījums (piemēram, nomas līgums) un kreditors nav izmantojis savas no komercdarïjuma izrietošãs prasības tiesības par līguma izpildī̌nanu vairāk nekā trīs gadus, saistība, kas nodibināta ar komercdarījumu (nomas līgumu), šajā brīdī nav noilgusi, bet ir noilgusi tikai daḷa no prasījumiem, kas izriet no šĩs ar darījumu nodibinātās saistības.

Arī pēc 2014. gada 1. oktobra rakstveida nomas līguma neesamības gadījumā tiesību normas nesniedz viennozīmīgu atbildi uz būtisku jautājumu: no kura brīža skaitāms noilguma tecējuma sākums, proti, kad ir radusies zemes îpašnieka prasījuma tiesība par zemes nomas maksas samaksu (ir iestājies nodibināta prasijuma samaksas termiņ̧̌). Lai gan no 2014. gada 1. oktobra līdz 2018. gada 1. janvārim tiesību normās viennozīmīgi bija noteiktas abas zemes piespiedu nomas tiesisko attiecību būtiskās sastāvdaḷas, joprojām diskutabls ir jautājums, kad iestājas parāda samaksas termin̦š, ja puses par to nav vienojušās. Pēc Valsts ieñēmumu dienesta paustā, tas iestājas ar sprieduma spēkā stāšanās 
brīdi, jo tiesas spriedums aizstāj aktu, kas nodibina maksāšanas pienākumu [70]. Pastāvot strīdam, piemēram, par nomas maksas aprēḳinu vai nomas maksai papildu maksājamo pievienotās vērtības nodokli, darījumu nevar atzìt par galīgi noslēgtu ar īpašuma tiesību iegūšanas faktu vien, lai gan saistība (par tās būtiskajām sastāvdal̦ām pušu starpā vēl ir strīds, un prasījuma tiesība nav atzīstama par nodibinātu) jau pastāv [36].

\section{Komerctiesiskā noilguma piemērošana piespiedu nomā}

Prasījuma tiesības piespiedu nomā var rasties uz likuma pamata: tās ir tiesības prasìt nomas attiecību konstatāciju vai nomas līguma noslēgšanu. Laikā starp 2014. gada 1. oktobri un 2017. gada 31. decembri ar likumu tika nodibinātas arī tiesības prasīt nomas maksas samaksu bez prasījuma konstatēt nomas attiecību vai līguma esamību. Saistības, pastāvot piespiedu nomas attiecībām, var rasties arī uz darījuma pamata, ja pušu starpā pastāv rakstveida nomas līgums. Pastāvot rakstveida līgumam, strīdu par prasijuma tiesību nodibināšanos un noilgumu ir mazāk - ja kāda no pusēm ir komersants, ir pamats piemērot noilgumu, kas noteikts prasijumiem, kas izriet no komercdarïjuma. Ja prasījuma tiesības ir radušās uz likuma pamata, katrā gadījumā jāvērtēe, kā tās radušās un kāds ir to saturs.

Tiesu praksē ir nostiprinājies viedoklis, ka prasījumiem, kas izriet no zemes nomas tiesiskajām attiecībām, ja zemes īpašnieks (prasītājs) ir komersants, vienmēr ir piemērojams saīsinātais komerctiesiskais noilgums [40]. Komercdarïjumu regulējums tiek piemērots arī tad, ja vienošanās par nomas attiecību būtiskajām sastāvdaḷām zemes īpašnieka un èkas dzīvokḷu īpašnieku starpā nav panākta, proti, nav konstatējama darījuma noslēgšana. Tomēr kritiski ir vērtējama hipotēze, ka visās saistībtiesiskās attiecībās, kas ir komerctiesiska rakstura, jāpiemēro Komerclikuma 406. pants un nav nozìmes prasijuma rašanās pamatam [14; 57]. İpaši kritiski jāvērtē šì apgalvojuma attiecināšana uz prasījumiem, kas izriet no piespiedu nomas tiesiskajām attiecībām, kad "uz likuma un tiesas sprieduma pamata pusēm izveidojas līgumam līdzīgas attiecības, bet ne līgums" [20, 12.2. punkts].

Komerclikuma 406. pants ietverts Komerclikuma D dạ̦ā "Komercdarījumi", tātad, sistēmiski tulkojot, tas attiecināms uz komercdarījumiem. Lai piemērotu šo prasījuma tiesību noilguma terminu, vispirms nepieciešams konstatēt, ka starp pusēm ir noslēgts komercdarījums. Termina "komercdarījums" legāldefinīcija sniegta Komerclikuma 388. pantā, pietiekami skaidri norādot, ka "komercdarījumi" ir komersanta "tiesiskie darījumi", kas saistīti ar komercdarbību. Lai gan Komerclikumā nav sniegts jēdziena "tiesiskie darījumi" skaidrojums, no Komerclikuma 3. panta pirmās un otrās daḷas izriet, ka šā jēdziena skaidrojums meklējams Civillikumā, kura normas piemērojamas komercattiecībās, ja Komerclikums vai cits komercdarbību regulējošais likums attiecīgo jautājumu neregulē [30].

Prasījuma tiesības var rasties gan uz likuma, gan tiesiska darïjuma pamata. Par komercdarījumu var atzìt tikai tiesisku darījumu. Arī komersantam gan prasījuma tiesỉbas, gan samaksas pienākums var rasties gan uz likuma, gan neatḷautas darbỉbas, gan 
darïjuma pamata. Apgalvojums, ka Komerclikuma 406. panta tvērums attiecas uz ikvienu komersanta prasījumu, ir pārāk plašs. Judikatūrā norādīts, ka ir komersantu prasījumi, uz kuriem komerctiesiskais noilgums nav attiecināms, jo tie nav komercdarïjumi. Tādi, piemēram, ir prasījumi, kas izriet no pilnvarojuma līguma [13; 45]. Arī attiecībā uz ìpašuma prasībām nebūtu pamata piemērot komerctiesisko noilgumu. Šie ir prasījumi, kas radušies uz likuma pamata, līdzīgi kā prasījums par zemes nomas tiesisko attiecību konstatāciju un no tā izrietošais parāda piedziṇas prasījums. Tādējādi nav pamata pieṇēmumam, ka komerctiesiskais noilgums būtu piemērojams arī attiecỉbā uz prasỉjumiem, kas izriet no saistībām, kas nodibinātas uz likuma pamata. Arī gadījumos, ja kāda no nomas attiecību pusēm ir komersants (ēkas vai zemes īpašnieks vai viens no kopīpašniekiem ir komersants), ja šo nomas tiesisko attiecību un no tām izrietošo prasijumu pamats ir tikai likums, proti, darījums pušu starpā nav noslēgts, šìs zemes piespiedu nomas attiecības nevar uzskatìt par komercdarïjumu Komerclikuma 388. panta izpratnē [46].

Noilgums prasijuma tiesībām, kas izriet no saistības, kas radusies uz likuma pamata, nav atkarīgs no saistības subjekta (kreditora vai parādnieka) ierakstīšanas komercreǵistrā, bet ir atkarīgs no prasijuma tiesību rašanās pamata. Zemes īpašnieka motīviem, iegūstot īpašumā zemes gabalu, nav tiesiskas nozīmes, ja prasijuma tiesības neizriet no komercdarījuma [7]. Tāpat tiesiskas nozìmes attiecỉbā uz piespiedu nomas attiecībām nav arī dzīvokḷa īpašnieka motīviem, iegādājoties dzìvokḷa īpašumu. No Civillikuma 1449. panta izriet, ka darījuma iemesli darījuma spēku neietekmē. Darỉjuma motīvi ir attiecināmi uz sākotnējo, jau izpildīto darījumu vai administratīvo aktu, kura izpildes rezultātā ir zemesgrāmatā nostiprinātas zemes îpašnieka īpašuma tiesības [11].

Dzīvokḷa îpašnieks (privatizētājs vai tā ieguvējs) - neatkarīgi, vai tā ir juridiska vai fiziska persona - nav atzīstams par mazāk aizsargātu tiesiskās attiecības dalībnieku, kā tas būtu raksturīgi patērētāja un pakalpojumu sniedzēja attiecībās. Kā vienam, tā otram iespēja pārtraukt savstarpējās nomas tiesiskās attiecības ir, vienīgi atsavinot savu īpašumu. Abu pušu īpašuma tiesỉbas ir ierobežotas, un, iespējams, zemes īpašnieka īpašuma tiesību aprobežojums ir pat būtiskāks, jo viṇam faktiski nav iespējas lietot savu īpašumu un īpašuma tiesības reāli nav izlietojamas [60, 5]. Abu pušu griba ir ierobežota, kas nav raksturīgs komerctiesiskai attiecībai. Ja puses nav brīvprātīgi noslēgušas nomas līgumu, piespiedu noma pēc izcelsmes veida un pazīmēm nav atzīstama par darïjumu, vēl mazāk - par komercdarījumu [48].

Nevar atzit par juridiski korektu apgalvojumu, ka komersantam piespiedu nomas tiesiskās attiecības nav gluži uz likuma pamata radìtas saistību tiesības, bet vairāk ar līgumisku raksturu. Gluži pretēji, arī judikatūrā ir atzìts, ka "piespiedu nomas attiecības nav risināmas tipisku saistību tiesību ietvarā", jo īpašuma reformas rezultātā izveidojies zemes lietojums pastāv kā ar likumu noteiktas zemes īpašnieka tiesības saṇemt nomas maksu un èku ìpašnieka tiesības lietot zemi un pienākums veikt samaksu par lietoto nomas priekšmetu [18]. Jauktu saistības nodibināšanās pamatu Civillikuma 1402. pants neparedz. Likumdevējs ir izvēlējies ēkas un zemes īpašnieka tiesiskās attiecības regulēt atbilstoši nomas līguma noteikumiem, tāpēc šajās attiecībās ir līgumiskais elements, 
piemēram, jautājumā par būtiskajām nomas attiecību sastāvdaļām. Tomēr šis līgumiskais elements pats par sevi tiesiskās attiecības nepārvērš par darījumu.

\begin{abstract}
“Saskaṇā ar objektīvo sistēmu tiesiskais darījums ir atzīstams par komercdarījumu, ja tam piemīt pazīmes, kādas objektīvi raksturīgas komerctiesiskajā apgrozībā noslēgtam darījumam. [..] Komercdarījumā, tāpat kā jebkurā citā tiesiskā darījumā, saskaṇā ar Civillikuma 1427. pantu ir nepieciešams personas gribas izteikums. Ja noslēdzamais komercdarījums ir daudzpusējs tiesiskais darījums, piemēram, līgums, tā noslēgšanai ir nepieciešami saskanīgi visu dalïbnieku gribas izteikumi." [55]

“Zemes īpašnieka un daudzdzīvokḷu dzīvojamās mājas īpašnieku savstarpējās attiecības ir dalītā [..] rezultāts [..]. Šādos gadījumos ēkas īpašnieka un zemes īpašnieka savstarpējās tiesiskās attiecības par zemes lietošanu nodibina likums. Konkrētajā gadījumā komersants neizsaka savu gribu ne par zemes gabala platību, ne par maksājamo apmēru, to nosaka likums." [42]
\end{abstract}

Nav tiesiska pamata likuma normas, kas regulē tiesiskus darījumus un gribas izteikumus, pēc analog̣ijas piemērot arī uz likuma pamata nodibinātām civiltiesiskām attiecībām. Lai izmantotu analog̣iju, ir jāvērtē normas jēga un mērḳis, kā arī jākonstatē atklāts likuma robs - likuma plānam pretēja nepilnība [56, 129, 133].

Komerclikuma 406. panta tvēruma paplašināšana pēc analogijas un tā piemērošana arī "darījumiem līdzīgām attiecībām", kurās nav viennozīmīgi konstatējami darījuma elementi, to skaitā nedz darījuma noslēgšanas brīdis vai prasijjumu par maksājumu veikšanu rašanās brīdis, nonāk pretrunā Satversmes 105. pantam. Satversmes 105. pants ietver tiesības gūt no lietas visus iespējamos labumus, tostarp ienākumus un augḷus, un liedz ipašuma tiesības ierobežot uz analoǵijas pamata [50, 10. punkts; 51, 12. punkts]. Saīsināta noilguma termiṇa piemērošana prasījuma tiesībām ir atzīstama par īpašuma tiesību aprobežošanu. Nav piel̦aujams izmantot indukciju (argumentu no mazākā uz lielāko, no konkrētā uz vispārējo), paplašinot analogijas tvērumu, nepamatojot šo nepieciešamību.

No otras puses, Augstākā tiesa vairākās lietās ir atzinusi, ka tikai ar sprieduma spēkā stāšanās brīdi ir konstatējamas visas darījuma būtiskās sastāvdaḷas, un, ja vispār var runāt par darījuma noslēgšanu piespiedu nomas gadījumā, tas uzskatāms par noslēgtu, tikai stājoties spēkā šim spriedumam [17; 18]. Judikatūrā ir vienprātīgi atzīts, ka piespiedu nomas tiesisko attiecību pastāvēšanas gadījumā, kamēr pastāv strīds par maksājamo nomas maksu un parāda summas apmēru, nevar pat runāt par nomas maksas samaksas kavējumu [15]. Ja nav samaksas kavējuma, prasījums nevar noilgt. Tādējādi laikā, kamēr nav nodibināta parāda summa, zemes īpašniekam ir prasības tiesības par zemes nomas līguma būtisko sastāvdaḷu konstatāciju, un šis prasījums, kā vairums saistībtiesisko prasỉjumu, noilgst desmit gadu laikā.

Domājams, nemaz netiktu uzsākta diskusija par to, vai prasijumiem, kas izriet no piespiedu nomas tiesiskajām attiecībām, būtu jāpiemēro Komerclikuma normas, ja Civillikuma vispārējais noilgumu regulējums paredzētu īsākus prasības noilguma termiṇus. Lielā dal̦ā Eiropas valstu ir veikta civiltiesisko attiecību regulējošo tiesību normu 
modernizācija, tostarp saīsinot prasības noilguma terminuus [63, 14]. 10 gadu noilguma termin,š bija saprātīgs pirms 150 vai 100 gadiem, tomēr mūsdienu tiesiskās apgrozības ātrums liek padomāt, vai arī Latvijas likumdevējam nebūtu jāveic šo normu grozỉjumi, lìdz pieciem vai pat trim gadiem saīsinot termiṇu, kurā var realizēt arī uz likuma pamata radušās prasījuma tiesības.

No minētā izriet, ka nav pareizs secinājums, ka piespiedu nomas tiesiskajās attiecībās, ja vismaz viens no attiecību dalïbniekiem ir komersants, ir piemērojams Komerclikuma 406. pants, un nav nozìmes prasijuma rašanās pamatam. Prasījuma pamatam ir tiesiska nozìme, vērtējot prasījuma tiesību noilgumu. Vienlaikus, lai nodrošinātu regulējuma atbilstību mūsdienu civiltiesiskās apgrozības àtrumam, Civillikuma 1895. pants būtu jāgroza, nosakot, ka prasījuma tiesības noilgst, ja tās nav izlietotas triju gadu laikā.

\section{Noilguma tecējuma pārtraukums}

Atbilstoši Civillikuma 1905. pantam noilgumu pārtrauc atgādinājums parādniekam. Tāpat noilgumu pārtrauc arī prasības celšana tiesā, ja tiesā lieta tiek ierosināta [58]. Praksē strīdus rada jautājums, vai par atgādinājumu dzīvokḷa īpašniekam var uzskatīt èkas pārvaldniekam (dzīvokḷa īpašnieka pilnvarniekam) nosūtītu atgādinājumu. Par labu šim argumentam runā Augstākās tiesas atziñas lietā Nr. SKC-250/2017 [26], kā arī likuma "Par valsts un pašvaldību dzīvojamo māju privatizāciju" 54. panta ceturtās daḷas un Dzīvojamo māju pārvaldǐšanas likuma 6 . panta otrās daḷas 4 . punkta, $17 .^{2}$ panta otrās daḷas, 17. ${ }^{7}$ panta un pārejas noteikumu 17.-19. punkta sistēmiska interpretācija.

Attiecībā uz ēkām, kuras apsaimnieko vēl pašvaldības izraudzīts pārvaldnieks, Augstākā tiesa ir norādījusi, ka pašvaldības pilnvarojums atbilstoši likuma "Par valsts un pašvaldību dzīvojamo māju privatizāciju" normām nozīmē arī uzdevumu un pilnvarojumu slēgt zemesgabala nomas līgumus ar zemesgabala îpašniekiem [26]. Tā likuma 50. panta pirmās daḷas 3. punktā noteikts, ka dzīvokḷa ìpašnieka pienākums ir slēgt zemes nomas līgumu vai pilnvarot dzīvojamās mājas pārvaldītāju un apsaimniekotāju slēgt zemes nomas līgumu ar tā zemesgabala ỉpašnieku (fizisko vai juridisko personu), uz kura atrodas privatizētais objekts. Šā panta septītajā dal̦ā noteikts, ka valsts dzīvojamās mājas valdītāja vai pašvaldības pienākums ir pārvaldìt dzīvojamo māju līdz tās pārvaldīšanas tiesību nodošanai dzīvokḷu īpašnieku sabiedrībai vai ar dzīvokḷu īpašnieku savstarpēju līgumu pilnvarotai personai. Ja dzīvokḷu īpašnieki dzīvojamo māju savā pārvaldīšanā nav pārn̦ēmuši, tad pašvaldība, t. i., tās pilnvarotā persona, turpina pārvaldìt dzīvojamo māju dzīvokḷu īpašnieku vārdā, tostarp pildīt pienākumu slēgt nomas līgumu ar zemes īpašnieku. Pašvaldība, vai precīzāk - tās vietnieks (piemēram, pašvaldības kapitālsabiedrības, kas izveidotas privatizēto ēku pārvaldīšanai) ir atzīstams par dzīvokḷu īpašnieku pilnvarnieku. Vēršanās ar atgādinājumu vai tiesā pret ēkas pārvaldnieku atbilstoši likuma "Par valsts un pašvaldību dzìvojamo māju privatizāciju" 54. panta ceturtās daḷas prasībām pārtrauc jebkādu noilgumu - gan saistību, gan prasības noilgumu. 
Šis princips attiecināms arī uz ēkas dzīvokḷu īpašnieku pilnvaroto personu, ja ēkas īpašnieki ir pārṇēmuši ēkas apsaimniekošanu. Dzīvojamo māju pārvaldīšanas likuma 6. panta otrās dal̦as 4. punktā noteikts, ka zemes nomas līguma slēgšana ir obligātā pārvaldīšanas darbība, savukārt 17. ${ }^{7}$ pantā dotas vispārējas norādes, ka zemes nomas līgums jāslēdz, ievērojot Civillikuma, citu likumu, kā arī šā likuma $17 .^{2}$ panta, izṇemot tā ceturto daḷu, noteikumus. Likuma $17{ }^{2}$ panta otrajā dạ̦ā paredzēts, ka dzīvokḷu ỉpašnieki pilnvaro vienu personu, kas var būt arī pārvaldnieks, pakalpojuma līguma noslēgšanai. Pilnvarotā persona slēdz pakalpojuma līgumu visu dzīvojamās mājas ỉpašnieku vārdā. Tā kā likuma pārejas noteikumu 17.-19. punktā noteikts, ka dzīvokḷu īpašniekiem vai pārvaldniekam ir jāinformē pakalpojumu sniedzējs (tātad arī zemes īpašnieks), izdarot izvēli par labu tiešajiem maksājumiem, zemes ìpašnieks atbilstoši minētajām tiesību normām var prezumēt, ka līdz šāda paziṇojuma saṇemšanai ēku pārvaldniekam ir tiesības slēgt zemes nomas līgumu ēkas ìpašnieku vārdā, secīgi pārvaldnieks ir atzīstams par pilnvarnieku (Dzīvojamo māju pārvaldīšanas likuma 11. panta pirmā daḷa, kurā noteikts, ka pārvaldī̌sanas tiesiskajās attiecībās, ciktāl tās neregulē šis likums, piemērojami Civillikuma noteikumi par pilnvarojuma līgumu, Civillikuma 2289. un 2306. pants) vai lietvedi (Civillikuma 2342. pants, kurā noteikts, ka pārstāvamā attiecības pret trešām personām, ar kurām lietvedim bijusi darǐšana, nosaka vispārējie noteikumi par vietniekiem), un atgādinājums pilnvarniekam vai lietvedim ir atzīstams par atgādinājumu pašam parādniekam.

Vēršanās ar pretenziju vai vēršanās tiesā pret ēkas pārvaldnieku pārtrauc jebkādu noilgumu - gan saistību, gan prasības noilgumu, ja vien dzīvokḷu îpašnieki nav paziņojuši zemes īpašniekam par izvēli veikt tiešos norēḳinus. Atbilstoši Civillikuma 1902. pantam saistības un prasības noilgumu pārtrauc tiesības izlietošana, ceḷot prasību tiesā, savukārt saistības noilgumu pārtrauc jebkurš atgādinājums parādniekam (Civillikuma 1905. pants) vai tā pārstāvim (Civillikuma 2298. pants, Dzīvojamo māju pārvaldīšanas likuma 11. pants, likuma "Par valsts un pašvaldību dzīvojamo māju privatizāciju" 50. panta pirmās daḷas 3. punkts un 54. panta ceturtā daḷa).

\section{Secinājumi}

1. Zemes īpašnieka prasījuma tiesības par zemes nomas tiesisko attiecību konstatāciju rodas no īpašuma tiesību nostiprināšanas zemesgrāmatā brīža par laikposmu no valdījuma iegūšanas brīža.

2. Prasijuma tiesības, kas izriet no jau noslēgta nomas līguma izpildes, rodas brīdī, kad prasījums ir tā nodibināts, lai varētu prasìt tā izpildi, t. i., nepastāvot pušu brīvprātīgam līgumam - no sprieduma, ar kuru nodibinātas nomas tiesisko attiecību būtiskās sastāvdal̦as, spēkā stāšanās brīža. Ar sprieduma spēkā stāšanās brīdi ir konstatējamas visas tiesiska darỉjuma būtiskās sastāvdal̦as un darījums uzskatāms par galīgi noslēgtu, un zemes īpašniekam ir radušās prasījuma tiesības par šì darïjuma izpildi - tiesības prasīt zemes nomas maksas samaksu. 
3. Prasījuma tiesības par zemes nomas tiesisko attiecību konstatāciju pret personu, kas veic daudzdzīvokḷu ēkas pārvaldīšanu un apsaimniekošanu, zemes īpašniekam rodas no brī̌za, kad pārvaldnieks ir pārṇēmis konkrētās ēkas pārvaldī̌̌anu un apsaimniekošanu, vai no zemes īpašuma tiesỉbu iegūšanas brǐža, atkarībā no tā, kas iestājies pēdējais. Tādas pašas prasījuma tiesības ir pārvaldniekam pret zemes īpašnieku, ja tas ir publiskas personas iecelts vai atbilstoši pilnvarots no dzīvokḷu ìpašnieku puses.

4. Prasījuma tiesības par zemes nomas tiesisko attiecỉbu konstatāciju pret atseviškiem dzīvokḷu īpašniekiem zemes īpašniekam ir radušās tikai kopš 2015. gada 1. oktobra, kad likums piel̦auj pakalpojumu sniedzējiem pieprasìt tiešos maksājumus no dzīvokḷ îpašniekiem par ēkas uzturēšanai nepieciešamajiem pakalpojumiem.

5. Nav tiesiskas nozīmes tam, uz kāda pamata zemes īpašnieks ir ieguvis īpašuma tiesības uz zemesgabalu, jo šis darïjums vai administratīvais akts ir izpildîts ar brīdi, kad ieguvēja īpašuma tiesības tika nostiprinātas zemesgrāmatā. Zemes īpašnieka tiesības prasìt nomas maksu izriet no lietu tiesības - ipašuma tiesībām uz zemesgabalu.

6. Prasījuma tiesību par zemes nomas maksas samaksu noilgumu pārtrauc gan atgādinājums vai vēršanās tiesā pret atsevišḳu dzīvokḷa īpašnieku, gan arī atgādinājums vai vēršanās tiesā pret ēkas pārvaldnieku, jo pēdējais, ja vien dzīvokḷu īpašnieki nav paziņojuši zemes ìpašniekam par izvēli veikt tiešos norēḳinus, ir uzskatāms par dzīvokḷu īpašnieku pilnvarnieku vai lietvedi.

\section{Limitation Period for Claims Arising from Compulsory Land Lease}

\section{Abstract}

After the restoration of the independence of the Republic of Latvia, within the framework of the initiated land reform, the legislature restored property rights of former owners or their heirs to the land which apartment houses were built on during the Soviet times, thus creating the basis for the so-called divided ownership. Legislator made a decision to regulate relationships between landowners and building owners as lease agreement. Although the legal relationship of compulsory land lease is established by law - the norms included in the law "On Land Reform in the Cities of the Republic of Latvia" and the law "On Privatisation of State and Local Government Residential Houses", there are different opinions as to whether legal relations between the parties could be classified as a legal transaction, or furthermore - as a commercial transaction, and, consequently, whether claims arising from compulsory land lease relations arise from the law or from a transaction. 
The aim of the research is to identify the moment when the right to claim has been established, which is a prerequisite for establishing the moment when the limitation period of the claim begins. It has been concluded in the research that it is necessary to distinguish between two claims a landowner can have: a claim to establish a legal relationship of land lease (conclude an agreement) and the claim in respect to execution of a concluded lease agreement - payment of the lease fee. The latter arises only after the conclusion of the agreement - either voluntarily or through the court; the limitation period for the claim arising from the concluded lease agreement begins at that moment.

The interpretation of legal norms and analysis of legal doctrine and judicature in the research resulted in the conclusion that the claim to bring an action to conclude a land lease contract against the manager of the apartment house rises for the landowner at the moment the manager has taken over the management of the respective house, or at the moment the land property rights were acquired, whichever comes last, while the claim to conclude a land lease contract against individual apartment owners for the landowner arose only after October 1, 2015, when the law allowed to request direct payments from apartment owners for the services required for maintenance of the building.

Keywords: compulsory land lease, transaction, commercial transaction, right to claim, claim, limitation period, commercial limitation period.

\section{Avoti un literatūra}

\section{Tiesību akti}

1. Civillikums. Ceturtā daḷa. Saistību tiesības: Latvijas Republikas likums: pieṇemts 28.01.1937. un spēkā no 01.03.1993. Valdības Vēstnesis. 46, 26.02.1937.

2. Dzīvojamo māju pārvaldīšanas likums: Latvijas Republikas likums: pieṇemts 04.06.2009. un spēkā no 01.01.2010. Latvijas Vēstnesis. 96(4082), 19.06.2009.

3. Dzīvokḷa ìpašuma likums: Latvijas Republikas likums: pieṇemts 28.10.2010. un spēkā no 01.01.2011. Latvijas Vēstnesis. 183(4375), 17.11.2010.

4. Grozījumi Dzīvojamo māju pārvaldīšanas likumā: Latvijas Republikas likums: pieṇemts 19.12.2013. un spēkā no 15.01.2014. Latvijas Vēstnesis. 6(5065). 09.01.2014.

5. Grozījumi likumā "Par valsts un pašvaldību dzīvojamo māju privatizāciju": Latvijas Republikas likums: pieṇemts 19.06.2014. un spēkā no 01.10.2014. Latvijas Vēstnesis. 131(5191), 08.07.2014.

6. Komerclikums: Latvijas Republikas likums: pieṇemts 13.04.2000. un spēkā no 01.01.2002. Latvijas Vēstnesis. 158/160(2069/2071), 04.05.2000.

7. Par iedzīvotāju ienākuma nodokli: Latvijas Republikas likums: pieṇemts 11.05.1993. un spēkā no 01.01.1994. Latvijas Vēstnesis. 32, 01.06.1993.

8. Par valsts īpašumu un tā konversijas pamatprincipiem: Latvijas Republikas Augstākās Padomes lēmums: pieṇemts 20.03.1991. un spēkā no 20.03.1991. Ziṇotājs. 19/20, 23.05.1991.

9. Par valsts un pašvaldību dzìvojamo māju privatizāciju: Latvijas Republikas likums: pieṇemts 21.06.1995. un spēkā no 25.07.1995. Ziņotājs. 16, 24.08.1995.

10. Par zemes reformu Latvijas Republikas pilsētās: Latvijas Republikas likums: pieṇemts 20.11.1991. un spēkā no 20.11.1991. Ziṇotājs. 49/50,19.12.1991.

11. Zemesgrāmatu likums: Latvijas Republikas likums: pieṇemts 22.12.1937. un spēkā no 05.04.1993. Ziṇotājs. 16, 29.04.1993. 


\section{Tiesu prakse}

12. Augstākās tiesas Civillietu departamenta 2014. gada 19. decembra lēmums lietā Nr. SKC3112/2014 (materiāli Nr. 3-10/0028).

13. Augstākās tiesas Civillietu departamenta 2015. gada 29. maija lēmums lietā Nr. SKC-2288/2015 (materiāli Nr. 3-10/0169/14).

14. Augstākās tiesas Civillietu departamenta 2015. gada 9. novembra spriedums lietā SKC-160/2015 (C27127610).

15. Augstākās tiesas Civillietu departamenta 2016. gada 4. marta spriedums lietā Nr. SKC-40/2016 (C27197411).

16. Augstākās tiesas Civillietu departamenta 2016. gada 20. aprīḷa spriedums lietā Nr. SKC-5/2016 (C29859011).

17. Augstākās tiesas Civillietu departamenta 2016. gada 26. oktobra spriedums lietā Nr. SKC336/2016 (C39057712).

18. Augstākās tiesas Civillietu departamenta 2016. gada 3. novembra spriedums lietā Nr. SKC255/2016 (C17116307).

19. Augstākās tiesas Civillietu departamenta 2016. gada 22. novembra spriedums lietā Nr. SKC226/2016 (C30458513).

20. Augstākās tiesas Civillietu departamenta 2016. gada 20. decembra spriedums lietā Nr. SKC349/2016 (C15248612).

21. Augstākās tiesas Civillietu departamenta 2016. gada 30. decembra spriedums lietā Nr. SKC343/2016 (C30208807).

22. Augstākās tiesas Civillietu departamenta 2017. gada 31. janvāra spriedums lietā Nr. SKC-11/2017 (C37068613).

23. Augstākās tiesas Civillietu departamenta 2017. gada 31. janvāra spriedums lietā Nr. SKC-69/2017 (C30171108).

24. Augstākās tiesas Civillietu departamenta 2017. gada 30. jūnija spriedums lietā Nr. SKC-244/2017 (C27128613).

25. Augstākās tiesas Civillietu departamenta 2017. gada 27. septembra spriedums lietā Nr. SKC180/2017 (C39069012). ECLI:LV:AT:2017:0927.C39069012.1.S.

26. Augstākās tiesas Civillietu departamenta 2017. gada 5. oktobra spriedums lietā Nr. SKC-250/2017 (C24186312), ECLI:LV:AT:2017:1005.C24186312.1.S.

27. Augstākās tiesas Civillietu departamenta 2017. gada 18. oktobra spriedums lietā Nr. SKC234/2017 (C39069114). ECLI:LV:AT:2017:1018.C39069114.1.S.

28. Augstākās tiesas Civillietu departamenta 2017. gada 6. novembra spriedums lietā Nr. SKC338/2017 (C30578513), ECLI:LV:AT:2017:1106.C30578513.1.S.

29. Augstākās tiesas Civillietu departamenta 2017. gada 8. decembra spriedums lietā Nr. SKC305/2017 (C39094314), ECLI:LV:AT:2017:1208.C39094314.1.S.

30. Augstākās tiesas Civillietu departamenta 2017. gada 19. decembra spriedums lietā Nr. SKC344/2017 (C33269614). ECLI:LV:AT:2017:1219.C33269614.1.S.

31. Augstākās tiesas Civillietu departamenta 2017. gada 20. decembra spriedums lietā Nr. SKC268/2017 (C30738312). ECLI:LV:AT:2017:1220.C30738312.1.S.

32. Augstākās tiesas Civillietu departamenta 2018. gada 15. marta lēmums lietā SKC-415/2018 (C32116205), ECLI:LV:AT:2018:0315.C32116205.2.L.

33. Augstākās tiesas Civillietu departamenta 2018. gada 27. jūnija spriedums lietā Nr. SKC-5/2018 (C39102313), ECLI:LV:AT:2018:0627.C39102313.1.S. 
34. Augstākās tiesas Rīcības sēdes 2015. gada 23. jūlija lēmums lietā SKC-1062/2015 (C39057712). 35. Augstākās tiesas Senāta Civillietu departamenta 2007. gada 29. augusta spriedums lietā Nr. SKC-535/2007.

36. Augstākās tiesas Senāta Civillietu departamenta 2007. gada 7. novembra spriedums lietā Nr. SKC-712/2007.

37. Augstākās tiesas Senāta Civillietu departamenta 2009. gada 25. februāra spriedums lietā Nr. SKC$71 / 2009$ (C33186205).

38. Augstākās tiesas Senāta Civillietu departamenta 2010. gada 15. septembra spriedums lietā Nr. SKC-174/2010 (C04355106).

39. Augstākās tiesas Senāta Civillietu departamenta 2011. gada 13. aprīḷa spriedums lietā Nr. SKC-43/2011.

40. Augstākās tiesas Senāta 2019. gada 30. maija spriedums lietā Nr. SKC-104/2019. ECLI:LV:AT:2019:0530.C30524615.3.S.

41. Augstākās tiesas Senāta 2019. gada 28. jūnija spriedums lietā Nr. SKC-3/2019 (C39101313). ECLI:LV:AT:2019:0628.C39101313.1.S.

42. Dobeles rajona tiesas 2017. gada 17. oktobra spriedums lietā Nr. C30452117.

43. Kurzemes apgabaltiesas Civillietu tiesu kolēgijas 2017. gada 19. decembra spriedums lietā Nr. C30471317, ECLI:LV:KUAT:2017:1219.C30471317.6.S.

44. Rīgas apgabaltiesas Civillietu tiesu kolēǵijas 2014. gada 24. februāra spriedums lietā Nr. C24114213.

45. Rìgas apgabaltiesas Civillietu tiesu kolēgijas 2017. gada 13. februāra spriedums lietā Nr. C30673715.

46. Rìgas apgabaltiesas Civillietu tiesas kolēgijas 2018. gada 26. oktobra spriedums lietā Nr. C31235916,

47. Rīgas pilsētas Vidzemes priekšpilsētas tiesas 2018. gada 3. maija spriedums lietā Nr. C32195817, ECLI:LV:RVPT:2018:0503.C32195817.3.S.

48. Rīgas rajona tiesas 2018. gada 16. marta spriedums lietā Nr. C33448217.

49. Satversmes tiesas 2009. gada 13. februāra spriedums lietā Nr. 2008-34-01. Latvijas Vēstnesis. 27(4013), 18.02.2009.

50. Satversmes tiesas 2009. gada 15. aprīla spriedums lietā Nr. 2008-36-01. Latvijas Vēstnesis. 60(4046), 21.04.2009.

51. Satversmes tiesas 2011. gada 27. janvāra spriedums lietā Nr. 2010-22-01. Latvijas Vēstnesis. 17(4415), 01.02.2011.

52. Satversmes tiesas 2011. gada 25. oktobra spriedums lietā Nr. 2011-01-01. Latvijas Vēstnesis. 171(4569), 28.10.2011.

53. Vidzemes rajona tiesas 2018. gada 23. aprīḷa spriedums lietā Nr. C33461617, ECLI:LV:VRT:2018:0423.C33461617.4.S.

54. Zemgales apgabaltiesas 2016. gada 21. aprīḷa lēmums, lietas arhīva Nr. CA-0235-16/13.

\section{Literatūra}

55. Balodis, K. 2009. Jaunais komercdarījumu regulējums un tā piemērošana. Jurista Vārds. 21(564).

56. Kalniņš, E. 2003. Tiesību tālākveidošana. No: Juridiskās metodes pamati. 11 soḷi tiesību normu piemērošanā: Rakstu krājums. Zin. red. E. Mel̦kisis. Rīga: Latvijas Universitāte.

57. Kārkliṇš, J. 2018. Noilgums piespiedu nomas attiecībās komerctiesībās. Jurista Vārds. 9(1015), 14.-19. lpp. 
58. Odiṇš, R. 2018. Par Civillikuma 1903. panta saturu. Latvijas Republikas Augstākās Tiesas Biletens. 16, 112.-114. lpp.

59. Rozenfelds, J. 2000. Lietu tiesības. Rīga: Zvaigzne ABC.

60. Rozenfelds, J. 2008. Pētījums par Civillikuma Lietu tiesību daḷas (ceturtās, piektās, sestās un septītās nodaḷas) modernizācijas nepieciešamību. Iegūts no: http://www.tm.gov.lv/files/archieve/ lv_documents_petijumi_cl_ceturta_piekta_sesta_un_septita_nodala.doc [sk. 30.09.2013.].

61. Snipe, A. 2018. Par saistības un prasības noilgumu saistībai, kas radusies uz likuma pamata. Jurista Vārds. 40(994), 23.-25. lpp.

62. Snipe, A. 2018. Satversmes tiesas konsekventā cinna ar Saeimas populismu. Jurista Vārds. 23(1029), 22.-29. lpp.

63. Swiss Insititute of Comparative Law. 2011. Gutachten zum Recht der Verjährung Deutschland, Frankreich, England und Dänemark. Avis 10-225, Lausanne. Iegūts no: https://www.bj.admin.ch/ $\mathrm{dam} / \mathrm{data} / \mathrm{bj} /$ wirtschaft/gesetzgebung/verjaehrungsfristen/gutachten-sir-d.pdf [sk. 26.06.2019.].

64. Torgāns, K. 2014. Saistību tiesības. Rīga: Tiesu namu aǵentūra.

65. Vīnzarājs, N. 2000. Civiltiesību problēmas. Raksti (1932.-1939.). Rīga: E. Kalniṇa un V. Tihonova izdevums.

\section{Interneta resursi}

66. Bērtule, A. 21.07.2017. Ieilgušas tiesvedības dēḷ no 700 dzīvokḷu īpašniekiem grib piedzìt parādu par zemes nomu. LSM.LV Iegūts no: https://www.lsm.lv/raksts/zinas/latvija/ieilgusastiesvedibas-del-no-700-dzivoklu-ipasniekiem-grib-piedzit-paradu-par-zemes-nomu.a220157/ [sk. 13.06.2018.].

67. Daudzdzīvokḷ namu īpašniekiem prasa samaksāt 10 gadus vecu nomas maksas parādu par zemi. LETA. TVNET.LV 27.02.2017. Iegūts no: https://www.tvnet.lv/4586821/daudzdzivoklu-namuipasniekiem-prasa-samaksat-10-gadus-vecu-nomas-maksas-paradu-par-zemi [sk. 13.06.2018.].

68. Informācija patērētājiem par SIA "Vienotais norēḳinu centrs" un AS "Pilsētas zemes dienests" darbību, pieprasot zemes nomas parādus. Patērētāju tiesību aizsardzības centra informācija patērētājiem. Patērētāju tiesību aizsardzības centrs. 2017. Iegūts no: http://ptac.gov.lv/lv/news/ informacija-pateretajiem-par-sia-vienotais-norekinu-centrs-un-pilsetas-zemes-dienests-darbibu [sk. 13.06.2018.].

69. Par atzinumu pārbaudes lietā Nr. 6-6/236. Latvijas Republikas Tiesībsargs. 26.08.2010. Iegūts no: https://ej.uz/CPL77 [sk. 13.06.2018.].

70. Par uzziṇas sniegšanu Nr. 8.11-20/63149. VID uzziṇas, vēstules. Valsts ieṇēmumu dienests. 01.08.2014. Iegūts no: https://www.vid.gov.lv/lv/vid-uzzinas-vestules [sk. 13.06.2018.].

71. Piespiedu nomas tiesisko attiecību aktuālie jautājumi. LR Tieslietu ministrijas informācija presei. Latvijas Republikas Tieslietu ministrija. 21.03.2017. Iegūts no: https://www.tm.gov.lv/ lv/aktualitates/tm-informacija-presei/piespiedu-nomas-tiesisko-attiecibu-aktualie-jautajumi-2 [sk. 15.05.2018.]. 